Article

\title{
The Power of Discourse: Reflections on the Obstacles to Social Inclusion of Roma in Serbia
}

\author{
Jelena Vidojević * and Natalija Perišić \\ Faculty of Political Sciences, University of Belgrade, 11000 Belgrade, Serbia; E-Mails: jelena.vidojevic@fpn.bg.ac.rs \\ (J.V.), natalija.perisic@fpn.bg.ac.rs (N.P.) \\ * Corresponding author
}

Submitted: 3 February 2015 | In Revised Form: 25 July 2015 | Accepted: 18 August 2015 |

Published: 29 September 2015

\begin{abstract}
The authors explore the discourses around the exclusion of the Roma in Serbia in two dimensions: social welfare sector and media reports. The paper is structured around the presentation of dimensions contributing to multiple deprivation of Roma in society (from education to labor market participation, social welfare and health care, as well as housing); a review of public policies directed toward the improvement of their position; and analysis of the discourses on Roma within the contexts of the social welfare sector and media reporting. A review of related literature and public policy documents was followed by a qualitative analysis of media reports as well as a review of the secondary sources regarding media discourses on the Roma. This was followed by evidence gathered from semi-structured interviews and discussions with stakeholders in the social welfare sector. The main conclusions of the paper point to the mutual reinforcement of the discourses on the Roma in the social welfare sector and media reports, with their subsequent mutual contribution to social exclusion.
\end{abstract}

\section{Keywords}

discourse; media; public policies; Roma; Serbia; social exclusion; social inclusion; social welfare

\section{Issue}

This article is part of the special issue "Talking about Roma: Implications for Social Inclusion", edited by Dr. Eben Friedman (Independent Consultant and Senior Non-resident Research Associate, European Centre for Minority Issues, Germany).

(C) 2015 by the authors; licensee Cogitatio (Lisbon, Portugal). This article is licensed under a Creative Commons Attribution 4.0 International License (CC BY).

\section{Introduction}

Vivid European-wide debates and dilemmas that surround the concepts of social inclusion and exclusion of Roma are numerous. National adaptations of the concepts and strategies directed toward social inclusion have been confronted with various political, economic, social, ethical and other challenges and restraints, without any definite solutions, but with a convincing body of "good" and "bad" practices that could provide useful input for policy reforms. In Serbia, these challenges seem to be severe and hard to eradicate, especially regarding the social inclusion of Roma, one of the most marginalized, misinterpreted and mistreated cul- tural and ethnic groups. The majority of these challenges seem to be shared, mainly with the neighbouring and ex-socialist countries, while few, if any, seem to be specific for the Serbian context, having mostly emerged during and after the transition of the 1990s. The main research questions of this paper are: what are the discourses on the social inclusion of Roma behind the official policies, as well as in mainstream media; and how do they contribute to the status quo regarding the Roma's unfavourable position. Therefore, the paper aims to present the official policies directed toward the social inclusion of Roma and also to analyse the "hidden" agendas supporting the survival of the status quo. The position of the Roma in Serbia, as pre- 
sented in the first chapter of this paper, displays the Roma as traditionally occupying a disadvantaged position in Serbian society, not only compared to their position in neighbouring countries, but also to other minority groups in Serbia. Public policies directed toward the Roma are presented within a historical perspective from the socialist period onward. A certain continuum of policies has existed, although their major common feature seems to be a continuous implementation trap. The reasons for this range from the absence of real political commitment for the improvement of the Roma's position, to underdeveloped measures and limited resources, and overt and latent discrimination against the Roma. In trying to present a nuanced picture of the obstacles to the social inclusion of Roma, the authors confined their discourse analysis in this paper to social welfare and media reports, mainly due to the importance of the social welfare system in addressing the problem of exclusion, and the role of media in shaping public opinion towards the Roma. The chapter on media representation analyses the picture that the media have been presenting to the citizens, heavily relying on stereotypes, prejudices, and sometimes even a hate speech. The chapter on social welfare tries to depict the "positions" of the Roma and other stakeholders in this sector, mainly the professionals and organizations working on their behalf and for their benefit. The main conclusion of the paper is that there is a strong correlation between the dominant discourse about the Roma and their position in society, despite the obvious urgency to make a difference.

\section{Poor and Socially Excluded: The Position of Roma in Serbian Society}

According to the 2011 Census, 147,000 Roma live in Serbia and they constitute $2.05 \%$ of the total population (Republic Statistical Office [RSO], 2012). However, secondary sources state that this number is significantly underestimated, and that the number of the Roma living in Serbia is at least double. There are several main factors that contribute to the fact that Roma often avoid declaring their ethnicity: frequent migrations; significant numbers who are not registered and therefore are "legally invisible"; and, due to the history of discrimination, Roma often resort to "social mimicry" in an attempt to integrate themselves into the wider community, "willingly" abandoning their own identity. In Serbia, the position of the Roma has been traditionally disadvantaged, even though their status during the socialist period was much better than in other Eastern European countries. Yugoslavia was considered to be the most progressive of states, and Roma had more space to develop their cultural autonomy (Sardelić, 2011). Integration was preferred to assimilation and Roma enjoyed a more secure social status. Also, their political participation was comparatively higher. After the dissolution of Yugoslavia and the transition to a market economy, their position changed for the worse, especially in terms of social exclusion and higher poverty rates, but also some stereotypes and prejudices have become even more emphasized. Studies show that the ethnic and social distance between them, expressed by the general population, is among the highest, along with that between Serbs and Albanians or Muslims/Bosniaks (Miladinović, 2008).

Poverty is widespread among the Roma population. It is multidimensional, usually accompanied by severe deprivation. It often results in social exclusion, which tends to be comprehensive, pervading and can be identified in almost every aspect of their lives. The main characteristics of their position are poor living conditions, poor educational levels, high unemployment rates and participation in the informal sector, as well as a low level of political participation that make them truly voiceless and, to use the language of postcolonial theory, subaltern. Roma who are internally displaced are the most disadvantaged (sub)group of all; they do not speak the Serbian language, and even their Roma dialect is quite different and not easily understandable in Serbia.

The vast majority of Roma live in more or less segregated, overpopulated settlements, generally lacking basic living conditions like clean running water and electricity, and usually unhygienic. There are 593 Roma settlements in Serbia, where nearly $70 \%$ of the country's total Roma population lives. Of those 593 settlements, 285 are in cities, while the rest are in suburban and rural areas. Only $28 \%$ were built according to formal plans, $25 \%$ were built illegally and $35 \%$ spread illegally from an originally planned core settlement (Cvejić, 2014). Spatial isolation has been seen as an important factor that contributes to further social isolation of Roma communities (Miladinović, 2008). During the past, resettlement of informal settlements was followed by evictions and a lack of adequate alternative housing, along with major human rights violations.

The right to education is recognized and guaranteed by several international documents and defined as a social, political and cultural right in the most important national legal acts. In spite of this, the educational structure of Serbia's Roma is traditionally unsatisfactory. Three main problems can be identified in this regard: Roma are not fully integrated in the educational system, they do not receive high quality education, and they are often exposed to discrimination and in some areas even to segregation. Almost one third of Roma do not have any education at all or have just a couple of years of basic education; one fifth has completed primary school, and only $11 \%$ and $1 \%$ graduated from secondary schools and universities or colleges respectively (Government of the RS [GRS], 2010). At the same time, the number of children covered by the preschool program is negligible (3.9\% compared to $40 \%$ of 
the children from the general population), which in combination with language barriers, is one of the main causes for poorer average performance of Roma pupils in schools, and one of the main factors that contributes to high percentage of their referrals into schools for children with special needs. Along with the language barrier, poor socioeconomic conditions significantly contribute to the poor educational performance of Roma children (Jovanović, 2013). It is estimated that around $50 \%$ of Roma parents do not send their children to schools due to a difficult material situation, and around $20 \%$ due to a lack of personal documents (GRS, 2010).

In 2007, the Ministry of Education recommended that schools provide for the enrolment of children whose parents do not possess a complete documentation, and in 2009, inclusive education was introduced. Despite initial positive results, largely limited to improved coverage and a higher enrolment rate, improvements will be temporary if not followed by more comprehensive approach (Jovanović, 2013). It is not sufficient to secure enrolment, but also to decrease drop-out rates and improve the quality of education. Drop-out rates from primary schools are extremely and comparatively high among Roma pupils and represent, among other things, a strong barrier to Roma children re-entering the mainstream education system. About $50 \%$ of Roma students drop out of school by the end of the fourth grade (Cvejić, 2014). Even though some progress has been made by means of affirmative action measures, the long term effects are yet to be seen.

An important source of Roma exclusion is the high unemployment and inactivity rate, despite their demographic characteristics and comparatively high proportion of young people. Low levels of education and vocational training, along with open or hidden discrimination by potential employers are considered to be the main reasons for Roma exclusion from the labour market, low levels of economic activity and lack of income generation. Roma are one of the most vulnerable and marginalized groups in the labor market, characterized by a very high unemployment rate, with extremely low quality of employment, and the prevalence of informal employment and engagement in the grey economy. The share of formally employed Roma is extremely low, and even where they are employed it is usually confined to informal, short term, unskilled and physically exhausting labor (Cvejić, 2014). Only 27.2\% of Roma are economically active, while the unemployment rate is three times higher than amongst the general population (GRS, 2010), and only $30 \%$ of employed Roma are covered by social insurance (Cvejić, Babović, \& Pudar, 2010).

Even though Serbia's Constitution and healthrelated laws assert that citizens and residents are universally entitled to health care, in practice this is strongly related to citizenship, residency and possession of healthcare booklets (Kaluski et al., 2014). Roma face several obstacles to achieving this, from incom- plete coverage by health insurance, limitations of the health care package covered by the public insurance system, the introduction of a participation fee and a lack of information about their entitlements. In 2009, $8.1 \%$ of Serbia's population was uninsured, while the rate amongst Roma was $24.7 \%$ (GRS, 2010). A lack of healthcare booklets is strongly associated with residency status, which makes refugees and internally displaced persons (within the Roma population) particularly disadvantaged. To obtain a healthcare booklet, citizens must be registered with authorities and obtain a government identity card. This requires them to provide proof of permanent residence and any of the following: birth certificate, working booklet, citizenship card or IDP (internally displaced persons) card. "Since many Roma in Serbia do not have a permanent place of residence and lack the ability to be included in the recognized work force-they cannot exercise their right to health care" (Kaluski et al., 2014, p. 6). Their health indicators are lower in comparison to those of the general population. The mortality rate of Roma children is two times higher, than the national average, and $20 \%$ of Roma children are ill conditioned (compared to $7 \%$ of children from the general population), while life expectancy is 10 years shorter (Cvejić et al., 2010). However, the Serbian Ministry of Health and the National Health Insurance Fund are taking measures in order to improve the access of Roma to healthcare by simplifying whole procedure and separating eligibility to health services from citizenship (Kaluski et al., 2014).

\section{Policies Affecting the Social Position of the Roma}

During the past two decades, Roma rights have been receiving increasing attention from the public and policymakers, largely due to the EU integration process. This has had a direct effect on the state's policies towards Roma. Legal protection of Roma has been improving as a part of this process, with Serbia seeking to fulfil the conditions of EU accession, as specified in the Copenhagen criteria. ${ }^{1}$ However, most studies show that the influence of the EU integration process is limited to mechanisms, rather than the actual conditions of minorities. Additionally, the sustainability of these measures is also questionable.

Current public policies affecting the social position of the Roma strongly reflect the policies conceived and implemented in Serbia during socialism (1945-1989) and transition (1990-2000). In that context, the postwar development of national policies concerning the Roma may be divided roughly into 3 phases, corresponding with the state's organization, underlying ideologies and dominant values in the public discourse of the respective period.

\footnotetext{
1 http://ec.europa.eu/enlargement/policy/glossary/terms/acces sion-criteria_en.htm
} 
Arguably, socialist Yugoslavia ${ }^{2}$ was an example of "how communist parties could actually have acceptable, progressive policies toward the Roma" (Barany, 2012, pp. 35-36). Policies at that time were aimed at Roma integration into society, first of all through education policies, through self-organization of Roma into autonomous cultural and social organizations, through agricultural land distribution policy, and finally through legally acknowledging their position as an ethnic minority. While the Roma were considered as an ethnic group in Yugoslavia and were granted equal rights, most notably in the 1974 Constitution, they were still, however, perceived as second-class citizens. The complex federal system of Yugoslavia was based on a hierarchy of rights, giving highest level of rights to its six constituent nations, while recognizing other nationalities at a lower level. This group of "other nationalities and ethnic groups," consisted of groups such as the Jews and the Roma (Sardelić, 2011). Despite the visibility of the Roma in the public sphere and the benefits they obtained based on equal rights, the practice saw some trends contradictory to those expected by policy makers. High numbers of Roma children were enrolled in schools for children with special needs, despite the actual absence of preconditions for this, while drop-out rates for Roma children were very high. Educational attainment among Roma was generally worse than among the rest of the population and also their living standard, despite improvement, was in general not satisfactory (Barany, 2012). Their membership within the Communist Party was extremely low, with only $0.15 \%$ of Roma (1,406 persons) joining (Mitrović \& Zajić, 1998). Part of the explanation for the failure of socialist policies toward the Roma is probably that their position in that period was so underprivileged that socialist policies should have been more encouraging with stronger affirmative action in order to produce relatively similar outcomes as those for other citizens. Furthermore, ever since socialism, many public policies, not only those regarding the Roma, have been confronted with serious problems in terms of implementation, with consequent adverse effects on the position of targeted populations.

Serbia's aspiration to join the European Union, articulated more or less constantly only since 2000 , has had a positive impact on the development of policies directed towards the Roma. Soon after this direction was adopted, Roma acquired minority status in 2002. In its policy papers, the Government officially acknowledged two facts, that were intuitively known, albeit without empirical evidence: the Roma were identified for the first time as one of the vulnerable groups in the 2003 Poverty Reduction Paper and also as a group exposed to discrimination and discriminatory actions in

2 Serbia was one of six Republics that constituted exYugoslavia. the 2013 Strategy for Prevention and Protection from Discrimination. The Roma population has been targeted in many national strategies with various focuses, including the 2009 National Strategy for the Improvement of the Position of the Roma, which was designed with the strategic aim of "improving the position of the Roma in the Republic of Serbia, with a view to reducing currently existing differences between the position of the Roma population and other inhabitants" (GRS, 2009 , p. 1). The Strategy identified thirteen areas of concern regarding the position of the Roma, with education, health, employment and housing declared the most important. All thirteen chapters contained, among other things, recommendations for further actions, aims and priorities in the period that was to follow (GRS, 2009). However hard it was to reconcile different perspectives on the Roma "question" and to incorporate them into national policies (and legislation) along with the criteria "imposed" by the European Union, the issue of policy implementation proved to be even harder. ${ }^{3}$ Notably, recent monitoring of the implementation of policies regarding the Roma conducted by several Roma organizations $\mathrm{s}^{4}$ focused on the $\mathrm{Na}$ tional Strategy for the Improvement of the Roma Position. The main findings are summarized below:

- None of 35 surveyed local communities had precise data and information about projects and funds directed towards the improvement of the position of the Roma on the local level in any of 13 areas identified in the Strategy;

- The majority of the surveyed local communities did not have Action Plans for the improvement of the position of the Roma. When the Action Plans for Education were present, there were no funds allocated for their realization. Action Plans for other areas identified in the Strategy were present very rarely;

- Extremely small number of measures provided in the Strategy has been realized, partially due to its recent enforcement, albeit with major breakthroughs in the area of Roma education (CPM et al., 2013, p. 9).

Along with these specific challenges, the challenge identified at all levels "still remains cooperation be-

\footnotetext{
3 One of the voices, that of one part of the Roma community in Serbia, finds out that the main cause of inefficiency of the $\mathrm{Na}$ tional Strategy for the Improvement of the Roma Position is the "absence of a decisive and unambiguous action against latent racism and discrimination" (Centar za prava manjina [CPM], YUROM Centar [YUROMC], \& Bibija, 2013, p. 5).

4 Stalna konferencija romskih udruženja građana (Permanent Conference of Roma Association of Citizens)-Liga Roma (League of the Roma) and Centar za prava manjina (Center for Minority Rights), Romski ženski centar "Bibija” (Roma Women Center "Bibija") and Yurom Centar (Yurom Center).
} 
tween different sectors, as well as the implementation of adopted legal regulations and other documents" (CPM et al., 2013, p. 9). The expected finalization of the above-mentioned Strategy (and also of the Decade of Roma Inclusion), was seriously confronted with the challenge of limited effects in terms of its realization in Serbia, and connected with the creation of a study (at the end of 2014) to serve as the basis for a new Strategy from 2015 to 2025.

The Preliminary Study is very critical of the previous Strategy on several points: 1) its failure to determine the social, economic, educational situation and societal position of the Roma; 2 ) its failure to define overall paradigms and 3) its failure to establish the actual numbers of the Roma to be covered by the measures (Bašić, Jovanović, Čolak, \& Ivanović, 2014, pp. 16-25). Therefore, the preconditions necessary to be fulfilled for the implementation of the Strategy and to be conceived for the following period are seen as the existence of a political will for its implementation, political and administrative responsibility and clear targeting (Bašić et al., 2014, pp. 37-39). An innovative approach is also offered through the proposed introduction of core values - freedom from deprivation, dignity, justice and human rights, while the governing principles expected to be useful are: 1) inclusion, 2) decentralization, 3) affirmative measures, 4) participation and subsidiary responsibility, 5) rationalization, efficiency and effectiveness (Bašić et al., 2014, pp. 39-45).

\section{Discourses about the Roma in the Social Welfare Sector}

Being the last resort for the vulnerable, the social welfare sector with its cash benefits and social services is one of the sectors the most relevant to the social inclusion process. In Serbia, means-tested social welfare is available where citizens have no employment options or are not able-bodied. Strictly speaking, the social inclusion concept was adopted only recently in the public policy governing the social welfare sector; it was accepted upon the intensification of the harmonization of the national legislation with the EU acquis (Vidojević, 2012). At the beginning of 2009, a proposal of a list of indicators for the monitoring of social inclusion was prepared. Its purpose was to serve as a basis for the intended creation of the First National Report on Social Inclusion and Poverty Reduction, which was followed by a Second National Report on Social Inclusion and Poverty Reduction released at the end of 2014. Meanwhile, in 2011, a new Law on Social Welfare was enacted, incorporating the concept of social inclusion as its objective (article 2 of the Law on Social Welfare).

Soon after, social exclusion has become one of the core areas of social policy in the national context. Based on the recommendations from the Annual Progress Report of the European Commission for Serbia in
2013, vulnerable social groups in Serbia started/continued to incorporate "women, children, persons with disabilities, Roma, refugees and internally displaced persons and the LGBT community" (GRS, 2014 , p. 44). The obvious reasons for Roma "membership" among these vulnerable groups are their permanently and extremely high poverty rates, along with severe social marginalization. The progress made in poverty reduction in Serbia during 2002-2006 did not have a proportionally positive impact on the Roma, while the current economic crisis has aggravated their situation and revealed the resistant nature of inequalities between them and rest of the population. After the outbreak of the crisis, it has become evident that heightened concerns about the consequences of longlasting and structured deprivation and social exclusion of the Roma cannot be overstated, calling for more efficient and effective policy measures.

However, the two-decade long transformation of the national social policy and consequent programmes and measures shows fundamental changes in the discourse on poverty and social exclusion of the Roma. Contrary to the socialist period, during which the state was supposed to care (or to "care") about them, the transition period introduced paradigms of personal responsibility, transferring a significant part of this obligations to the people themselves and their families. The normative context of social policy has changed to a great extent, especially in terms of dealing with social welfare benefits and services.

The new paradigm of social welfare legislation follows the discourse on the activation of (able-bodied) poor, requiring from them to find employment and depriving them of the right to cash benefits during any 3month period in a year. ${ }^{5}$ The repercussions of this shift for the Roma population are numerous, "ranging from eviction, exploitation, and dehumanization to difficulties for the Roma to effectively enact their legal citizenship rights" (van Baar, 2011, p. 191). With an unemployment rate of $17.6 \%$ and employment rate of only $40.6 \%$ among the general population (RSO, 2014), finding a job seems to present a serious challenge in the national context, not only for the Roma, but in particular for the Roma. Additionally, when taking into account the notorious fact of their dominant employment in the grey (informal) economy, it is almost impossible for Roma to comply with the requirements about official employment. The regulation on the number of family members that can be taken into account when determining the level of the social welfare cash benefit is also unfavourable for them: the number

\footnotetext{
${ }^{5}$ The right to cash benefit for an able-bodied beneficiary is limited to 9 months during a year. After that, in the following 3 months, they cannot effectuate this right. Upon the termination of the 3-month period, they can claim the right again (article 85 of the Law on Social Welfare).
} 
of family members is limited to six and the highest level of cash benefit is that for six-member families. A similar "solution" is found in the regulation of child allowances - the maximum number of children in one family eligible for the child allowance is limited to four. Bearing in mind that the Roma families and/or households are frequently extended ones (with grandparents, parents and children) and that they usually have more children, they are to a certain extent deprived of this right. The level of benefits is arguably the most contested issue; according to the latest available data in February 2014, cash benefit and the child allowance amounted to RSD 7,628, ${ }^{6}$ and RSD 2,568 respectively (Ministry of Labour, Employment and Social Policy [MLESP], 2014), while the minimum and average salaries amounted to RSD 18,400 and RSD 44,057 respectively (Paragraf, 2014). Thus, a Roma family of two parents and four (but also more) underage children is able to receive an amount a bit higher than the minimum salary and somewhat lower than half of the average salary. On the other hand, child allowance represents $13 \%$ of the minimal salary and only $5 \%$ of the average salary.

Contrary to the clear findings from poverty and social exclusion surveys on the average poverty rates among the Roma population, there are no official data about the numbers of the Roma taking advantage of the right to social welfare benefits and child allowances. There are, however, public documents ${ }^{7}$ pointing to many obstacles for the Roma when trying to claim their social welfare rights. Most frequently, they are confronted with the problem of the lack of personal documents. The process of claiming the social welfare benefits in the national context is extremely complex as it requires the compilation of numerous documents as evidence of the person's living circumstances. This is especially hard for Roma who have returned to Serbia based on readmission agreements, since they frequently do not have a single document on their status. However reasonable the absence of the data about the number of the Roma claimants, this in turn creates room for the creation and survival of certain myths. An over-representation of the Roma within social welfare beneficiaries would not be astonishing, due to two facts already mentioned: they are exposed to poverty

\footnotetext{
${ }^{6}$ The rules on the calculation of the level of benefits are such as follows: a single person in a family can receive the mentioned amount of RSD 7,628 (MLESP, 2014); All other eligible adult members in the family can receive half of this amount and all eligible children (i.e. persons under the age of 18 years of life) can receive one third of this amount (article 88 of the Law on Social Welfare).

7 Ombudsman's Report of 2014 on the implementation of the Strategy for the Improvement of the Roma Position and the Report of 2013 on the Monitoring of the implementation of policies directed toward the Roma by the Center for Minority Rights, YUROM Center and Bibija offer a lot of examples on current inability of the Roma to claim their rights.
}

and above average social exclusion; and their population is young, i.e. a lot of the Roma children (who are therefore non able-bodied) could be social welfare beneficiaries. ${ }^{8}$ A fact often neglected in public discourse generally is that the level of social welfare benefits does not enable their beneficiaries to escape from poverty and social exclusion. "Depending on the type and characteristics of households, monthly transfers should be raised by $33-45 \%$ in order to reach the poverty threshold" (GRS, 2014, p. 182).

However, the processes of the transformation of society have created complex public attitudes towards the poor and socially excluded, which is a mixture of compassion and antagonism, accompanied by rigid and frequently ambivalent assumptions and stereotypes about them. When a Roma person is added into this context, the process of "othering" becomes simpler for the domicile population (due to their ethnic background), while public attitudes become increasingly complex and can be briefly described as victimization of a victim, by labelling the Roma as the "deserving poor." Additionally, this notion, when applied to the Roma, was recently expanded as to include the socalled "transgressing poor"-along with the deserving aspect of poverty, it includes law breaking in cases of denied benefits, for the purpose of surviving (Standing, 2010). Because of their poverty, the Roma are seen as dependent, at least materially/financially. Professionals working in the social welfare sector are not always immune from overt and/or latent discrimination against their Roma beneficiaries. Speaking of them sporadically in terms of "generational users of welfare benefits," "phonies capable of doing anything in order to get the money from the state," "those who benefit from being the minority," some do not contribute to the deconstruction of deeply rooted stereotypes and even add to further confusion, discrimination and hostile attitudes of the public. Such attitudes of professionals contribute to the survival of the picture of the Roma's material dependency and also add another, even more dangerous component; it is their psychological dependence, exactly through its manifestation of "a dependent role which may be clinging, demanding, manipulative, pleading, or any number of these things by turns" (Spicker, 2011, p. 66). Then, the extreme and generational powerlessness of the Roma becomes neglected instantly, as well as the structural causes for such a situation. Such public "amnesia" and "excuses" for discrimination originate from the idea of reciprocity in social relations and exchange theory. Reciprocity describes the expectation of a person receiving something that they should do or not to do something in re-

\footnotetext{
8 The percentage of children within cash social welfare beneficiaries accounts for $36.8 \%$. Their participation is disproportional to their participation in the overall population of only $17.6 \%$ (GRS, 2014, p. 181).
} 
turn, based on a claim that there are no rights without obligations. Exchange theory goes on further, with the moral obligation toward the one who is giving - "it is morally improper...; to break off relations or to launch hostilities against those to whom you are still indebted"; (moral) supremacy of the giver over the receiver"a relationship in which the giver is more powerful than the receiver, because he can control aspects of the receiver's fate;" and finally there is a possibility of sanctioning the receiver- "the imbalance of power inherent in dependency may be used to the disadvantage of the dependent person" (Spicker, 2011, p. 67). On the one hand, misrepresentations of the position of the Roma by some professionals in the social welfare sector can be linked with traditional arguments against public welfare provision. Public welfare is paternalistic, while user perspectives and bottom-up approaches to policy making have only recently entered the agenda. All public services in the social welfare sector are systems of exchange, as per Pinker's classical essay Social Theory and Social Policy, accompanied potentially with stigma (Pinker, 1974). It is commonly believed that means-testing is stigmatizing, at least more than the insurance principle. "Above all, means-testing and other schemes based on selectivity criteria fail to satisfy any principle of social justice worthy of the name, because they tend not to reach those most in need of income support, a fact that research around the world has consistently demonstrated" (Standing, 2010, p. 58). Additionally, claiming the right to social welfare benefits requires the claimants to present arguably more documents than necessary. Consequentially, the Roma's auto-perception is frequently associated with stigma and humiliation, feeling of being intruded, loss of privacy and denied self-dignity, etc.

The above-mentioned attitudes among a section of the public and in part of the professional community characteristic of rigid and traditional views on minorities and social welfare beneficiaries are in a sharp contrast with the evidence-based statements in the recently released Second National Report on Social Inclusion and Poverty Reduction: "the position of the vulnerable social groups has been significantly improved..., but there is the need to make additional steps in certain areas. The process of improving of the Roma minority position has been continued, but the prescribed measures should be coordinated in order to have better effects in the practice. The Roma minority inhabitants have been still exposed to discrimination, especially regarding claiming their rights to social welfare and health care....special attention should be paid to the rights and inclusion of the vulnerable social groups, especially the Roma, and effective implementation of regulations on the rights of minorities, antidiscriminatory approach to minorities in the whole country..." (GRS, 2014, p. 20).

Clearly, there are many narratives in the public sec- tor consistent with the above-mentioned statement, first of all coming from professionals taking on other roles in their relations with the Roma beneficiaries. Secondly, some of the most distinguished examples are the Ombudsman and his office and the Commissioner for Protection of Equality who frequently raise their voices against discrimination toward the Roma and their disadvantaged position in society. The Ombudsman has pointed out many obstacles to the social and economic integration of the Roma and inconsistent policy measures aimed at the poverty reduction and actual realization of equality between the Roma and other inhabitants. He goes on to conclude that the affirmative action prescribed by the Constitution has not yet been operationalized to a sufficient level and thus does not present a way to overcome the extremely unfavourable social and economic position of the Roma (Ombudsman, 2014). The majority of claims about discrimination lodged with the Public Representative for Equality have been based on disability, but those based on ethnic background follow close behind, frequently referring to the discrimination related to the public services (Commissioner for Protection of Equality, 2014).

Other advocates of the poor and socially excluded Roma consist mainly of civil society organizations and non-Roma human rights activists. Frequently, it seems that they have much more understanding and empathy for the Roma and use more and authentic empowering approaches, encourage volunteers to support the Roma, mobilizing the public against Roma hardships and presenting consistently more conscious attitudes in public and in professional practice. Their activities range from the legal representation of the Roma to the everyday support of Roma children in the schools, empowering Roma women to confront domestic violence, etc. In their activism, NGOs apply different discourses, with three of them quite explicit and unequivocal: 1) the Roma are the most disadvantaged victims of discrimination for which 2) the state is to blame and 3) the Roma have rights that need to be politically recognized and protected (Schneeweis, 2009). In their activism, "NGOs are usually torn between different pressures, dynamics and loyalties, trying to formulate (support) solutions to the problem of the Roma which are in harmony with their commitment to the grassroots and to traditional and cultural stability; in agreement with their own organizational mission for social collaboration and participation; and in accord with national and international official political stance on integration" (Schneeweis, 2009, p. 270).

However, there are also arguments that could be directed against the proper representation of the Roma by the civil sector. There are several questions that need to be addressed. First and the most important of all is who has the legitimacy to be the voice of the Roma and represent their interests; NGO activists and 
leaders are often perceived as "experts" in that field, but unfortunately "professionalization, as part of an NGO-isation process, might not lead to more participation for the 'target group' or the grassroots. 'Project logic' pushes towards upwards vertical participation and not downward horizontal participation, and can lead to further concentration of power in the hands of administrators and technocrats. NGO-isation leads to transformation of a cause for a social change into a project with a plan, timetable and limited budget, which is 'owned' for reporting and used for the purposes of accountability vis-à-vis the funders" (Jad, 2010, p. 200). Even though NGOs are often presented as passive recipients of external influence, at the mercy of the whims of donors, they also have the power to manipulate, renegotiate, and legitimize donor agendas using funds earmarked to further their own agendas (Jad, 2010). Also, there are concerns about effectiveness of the strategies and approaches applied by NGOs. The main challenge to their functioning is finding financial sources, the lack of which can reduce their activities to a project type. Thanks to the Decade of Roma Inclusion, many national and international donors have been active in the field and Roma protection has been collecting huge financial funds, training and expertise. Therefore, the practice saw increased, not necessarily honest, devotion of civil sector organizations to projects aimed at the Roma inclusion.

Roma themselves and their organizations within the social welfare sector are rather rare. Distinguished Roma activists sometimes do not use their potential to the best for the improvement of the position of "ordinary" Roma who are confronted with a daily fight to survive and have very low capacity for (self)organization. According to the data of the Roma Information Centre, there are 72 Roma organizations in total in Serbia (Roma Information Centre [RIC], 2015). Where they exist in the social welfare sector, they fight mainly against poverty, for sending children to school and compiling necessary documents in order to be able to claim their rights.

The Roma are underrepresented as professionals in the social welfare sector, even though their role would be arguably extremely beneficial. This can be extrapolated from the data on achievements of the Roma health mediators engaged by the Ministry of Health. Within the Programme for the Improvement of Health and Health Care of the Roma, 75 Roma health mediators have become active in 59 local communities, dealing with activities aimed at increased health care access for the Roma (GRS, 2014).

\section{Media Representation of the Roma}

The mass media have the power to represent the world according to their own standards, and their responsibility for the way that certain social groups are presented lies in the fact that very often images of certain people, events and relationships are built on the basis of simplified elements that carry certain meanings (Kleut, Drašković, \& Prodanović, 2012). Media, among other things, contribute to continuing of reproduction of hegemonic ideologies, but also, more importantly, to positioning individuals, or even whole groups, in accordance with such ideologies (Sardelić, 2011). Therefore, the media has the power to reinforce racial and ethnic inequalities and barriers in society.

The role of the media in creating and/or shaping attitudes toward the Roma is substantial. Recent research has indicated that media reports represent the main source of information about the Roma for the more than $60 \%$ of citizens of the Republic of Serbia. The research also showed that Roma are perceived as the most discriminated against group in the society but, at the same time, people were not sufficiently aware of how severe their living conditions are (CESID, 2013).

Stories about Roma are generally produced by nonRoma media and are typically stereotypical. This has many implications for the way the Roma are represented. The image of the Roma created in the mainstream media fits into a larger "ambiguous" picture about equality and diversity in contemporary Europe. Representations range from images of poverty and crime to romanticizing the Roma other as inherently nomadic and bohemian ("symbolically privileged, and socially marginalized") (Schneeweis, 2009). This approach draws on a long tradition of literary and artistic representation dating from the era of romanticism. The Roma are portrayed through a musical, artistic, free spirited, romantic and bohemian character. This image was pervasive during communism, but since the transition it has been slowly abandoned.

Even though we cannot speak about public and direct display of discrimination, prejudice and hate speech in the media, various strategies are used to get around this. Stereotyping is one of the strategies that the media frequently uses while representing the "other", which is proven to be very successful in preserving positions of power and influence within society. Stereotypes are never neutral, but strongly motivated by certain interests. The notion of stereotyping means that there is a continuous repetition of certain images regarding specific social groups, which includes taking a set of characteristics that could be easily understood believing that they belong to a certain group, and then based on this creating an =image of the whole group (Mek Kvin, 2003, p. 183, in Kleut et al., 2012). There is a strong correlation between the representation of the Roma, and the representation of the poor, including the application of two different strategies with similar outcomes: the strategy of symbolic marginalization and the strategy of symbolic normalisation. The first strategy is to represent the other through stereotypes, as extremes within the society, lacking 
basic living conditions. The second strategy tries to represent them as a totality of society, without a name, reduced to numbers and statistics (Kleut et al., 2012). Using the strategy of symbolic marginalization, poverty is presented in its extreme form. Also, bureaucratic statistical vocabulary is usually used, without in-depth analysis and explanation of the context. The poor do not have an opportunity to articulate their own problems, to tell their own stories. With a denial of the subjectivity to the poor, it is suggested that they are not capable dealing with their own problems, and that they are completely dependent on the state (Kleut et al., 2012). Stories are usually accompanied by images of deprivation, determinism and victimization that have a tendency to become a repetitive story, while their poverty usually becomes an ethnic issue. The strategy of marginalization represent poverty as a problem of a small group of people. While the strategy of symbolic normalization, the poverty is generalized as the problem of the whole population of the Republic of Serbia. This strategy corresponds with the deepest feelings of the citizens, following the principle of "anti-stereotyping" and it is characterised by the general feeling of poverty.

The representation of Roma strongly relates to the strategy of a symbolic marginalization, which is based on an oversimplified and stereotyped images where behavior is represented as a deviation from the social norm and is followed by visualizations which make these images more striking, creating an impression that only a limited group of people are facing it. With the minority, represented as "they", the mass audience cannot identify and for the majority of the audience denying the position of interested party, and therefore the interest to initiate broadening the discussion on poverty reduction, but also on the roots of poverty.

Regardless of the strategy used, the poor are usually denied of their own definition of reality in much the same way as the Roma. What makes the situation more complicated is the tendency of professionalism decrease in the media, manifested, among other things, through sensationalism and political instrumentalisation (Simeunović Bajić, 2011).

Although discrimination against the Roma takes a wide range of different forms, only the most severe expressions of violence attract media attention. When Roma are the subject of violence, media are usually indifferent or show signs of the "spiral of silence".

\section{Conclusion}

The Roma did not become marginalized and discriminated against after the transition. Rather, their marginalization and discrimination was constructed based on elements of the approach taken towards them during the socialist period (Sardelić, 2011). Still, com- pared to the subsequent periods, the socialist period of the development of policy towards the Roma could be described as positive, while the later periods could be qualified as completely the opposite. Serbia's transition during the 1990s was characterized by the denunciation of positive socialist values and principles and their translation into the liberal ones. The liberal paradigm of personal responsibility for one's own life and choices did not favour any policies in support of the Roma (or other vulnerable groups in society). Additionally, the specific situation of a total economic collapse and war in the country's immediate vicinity (in which Serbia participated), and the large-scale poverty which accompanied it, favoured the flourishing of extremely discriminatory practices and high levels of intolerance directed against the Roma. In this period, there was no major policy development regarding the Roma and previously enacted policies were not implemented. Therefore, this period presented a kind of vacuum with little devotion to minority rights in general. During the last two decades, however, Roma rights have become an important part of the policy debate and reform, largely due to EU integration process. Certain mechanisms are in place but still need to be put in motion. Along with policy reform, the dominant narrative on the Roma, and their media representation, needs to be fundamentally transformed.

Two recommendations for the improvement of the position of the Roma within the social welfare sector could be to try to make stronger and more reliable ties between the public and civil sectors, with the participation of the Roma community, by including their perspectives. This would be in line with the efforts aimed at creating opportunities for beneficiaries to make their own contribution. Another, compatible line would be their activation. However, the activation concept in the social welfare sector that was presented in the paper has severe disadvantages to the beneficiaries and preferably the state should be activated prior to its citizens.

The media can have an important role in changing the perception on the Roma. So far, media reports have been based on stereotyping, heavily relying on "poverty porn", which has contributed to maintaining the status quo when it comes to the Roma's position in the society. The Roma are kept in a representation mode that is different, separate and less civilized, and they are usually depicted as poor thieves and beggars; immoral and amoral with socially unacceptable lifestyles; inactive, dependent and lazy. Pictures that are used for visualization usually present poor living conditions; houses surrounded by garbage and waste, usually without in-depth analysis of the context.

\section{Conflict of Interests}

The authors declare no conflict of interests. 


\section{References}

Barany, Z. (2012). Politics and the Roma in StateSocialist Eastern Europe. In A. Pusca (Ed.), Eastern European Roma in the EU-Mobility, discrimination, solutions (pp. 27-46). New York, London, Amsterdam: International Debate Education Association.

Bašić, G., Jovanović, V., Čolak, A., \& Ivanović, J. (2014). Polazna studija za izradu strategije za inkluziju Roma u Srbiji usaglašene sa Strategijom Evropa 2020. Retrieved from http://www.romskinacionalnisavet. org.rs/files/POLAZNA STUDIJA oktobar_2014.pdf

Centar za prava manjina, YUROM Centar, Bibija. (2013). Praćenje sprovođenja romskih politika na nacionalnom i lokalnom nivou u Republici Srbiji. Belgrade: Centar za prava manjina, YUROM Centar, Bibija.

CESID. (2013). Istraživanje javnog mnjenja: odnos građana prema Romima u Republici Srbiji. Retrieved from http://www.cesid.org/images/136456 9004_Medijska\%20analiza.pdf

Commissioner for Protection of Equality. (2014). Za Srbiju bez diskriminacije-Vodič kroz institucionalnu zaštitu od diskriminacije nacionalnih manjina. Belgrade: Zastupnik za ravnopravnost.

Cvejić, S. (2014). Faces and causes of Roma marginalization: experiences from Serbia. In J. Szalai \& V. Zentai (Eds.), Faces and causes of Roma marginalisation in local contexts (pp. 97-127). Budapest: Center for Policy Studies.

Cvejić, S., Babović, M., \& Pudar, G. (2010). Human development study-Serbia 2010: Sources and outcomes of social exclusion. Retrieved from http://www.secons.net/admin/app/webroot/files/ publications/hdrbook.pdf

Government of the RS. (2009). Strategija za unapređenje položaja Roma u Republici Srbiji. Retrieved from http://www.inkluzija.gov.rs/wp-content/uploads/ 2010/03/Strategija-SR-web-FINAL.pdf

Government of the RS. (2014). Drugi nacionalni izveštaj o socijalnom uključivanju i smanjenju siromaštva u Republici Srbiji. Belgrade: Vlada Republike Srbije. Retrieved from http://www.inkluzija.gov.rs/wpcontent/uploads/2010/03/Strategija-SR-webFINAL.pdf

Jad, I. (2010). NGOs: between buzzwords and social movements. In A. Cornwall \& D. Eade (Eds.), Deconstructing development discourse: Buzzwords and fuzzwords (pp. 193-203). Oxford: Practical Action Publishing Ltd. in association with Oxfam GB.

Jovanović, V. (Ed.) (2013). Obrazovna inluzija dece romske nacionalnosti: Izveštaj o sprovedenom monitoringu u osnovnoškolskom obrazovanju. Belgrade: Centar za obrazovne politike.

Kaluski, D. N., Stojanovski, K., McWeeney, G., Paunović, E., Ostlin, P., Licari, L., \& Jakab, Z. (2014). Health insurance and accessibility to health services among Roma in settlements in Belgrade, Serbia-The jour- ney from data to policy making. Health Policy and Planning, 2014, 1-9.

Kleut, J., Drašković, B., \& Prodanović, D. (2012). Predstavljanje siromašnih u srpskim medijima. In B. Dimitrijević (Ed.), Kriza i perspektive znanja i nauka (pp. 412-426). Niš: Filozofski fakultet u Nišu.

Miladinović, S. (2008). Etnička i socijalna distanca prema Romima. Sociološki pregled, XIII(3), 417-437.

Ministry of Labour, Employment and Social Policy. (2014). Visine socijalnih davanja. Retrieved from http://www.minrzs.gov.rs/cir/arhiva/visinesocijalnih-davanja

Mitrović, A., \& Zajić, G. (1998). Društveni položaj Roma u Srbiji. In G. Svilanović \& D. Radovanović (Eds.), Romi u Srbiji (pp. 9-64). Belgrade: Centar za anti-ratnu akciju, Institut za kriminološka i sociološka istraživanja.

Ombudsman. (2014). Izveštaj o sprovođenju Strategije za unapređenje položaja Roma sa preporukama. Retrieved from http://www.pravamanjina.rs/attach ments/IZVESTAJ\%20ZG\%200\%20SPROVODJENJU\%2 OSTRATEGIJE.pdf

Paragraf. (2014). Statistika. Retrieved from http:// www.paragraf.rs/statistika/01_stat.htm

Pinker, R. (1974). Socijalna teorija i socijalna politika. Zagreb: Savez društava socijalnih radnika Socijalističke Republike Hrvatske.

Republic Statistical Office. (2012). Popis-2011. Belgrade: Republički zavod za statistiku.

Republic Statistical Office. (2014). Anketa o radnoj snazi u Republici Srbiji-III kvartal 2014. Belgrade: Republički zavod za statistiku.

RIC. (2015). Romske organizacije. Retrieved from http://www.ric.org.rs/cms/index.php?option=com_ content $\&$ task=section $\&$ id $=4 \&$ Itemid $=29$

Sardelić, J. (2011). Constructing or repositioning Roma in post-socialist Slovenia and Croatia? (Unpublished Master thesis). Central European University, Budapest, Hungary.

Schneeweis, A. A. G. (2009). Talking difference: Discourses about Gypsy/Roma in Europe since 1989 (Unpublished Doctoral dissertation). University of Minnesota, USA.

Simeunović Bajić, N. (2011). Roma in Serbia after the collapse of Yugoslavia: Political implications and media silence on racial violence. European Journal of Interdisciplinary Studies, 3(2), 87-93.

Spicker, P. (2011). Stigma and social welfare. Bristol: Policy Press.

Standing, G. (2010). Social protection. In A. Cornwall \& D. Eade (Eds.), Deconstructing development discourse: Buzzwords and fuzzwords (pp. 53-69). Oxford: Practical Action Publishing Ltd. in association with Oxfam GB.

The law on social welfare (2011). Retrieved from http://www.paragraf.rs/propisi_download/zakon_o _socijalnoj_zastiti.pdf

van Baar, H. (2011). The European Roma-Minority rep- 
resentation, memory and the limits of transnational governmentality (Unpublished Doctoral dissertation). University of Amsterdam, The Netherlands.

Vidojević, J. (2012). Konceptualizovanje socijalne uključenosti u Srbiji-Karakteristike i osnovni aspekti socijalne isključenosti. In Z. Stojiljković (Ed.), Lavirinti tranzicije (pp. 137-154). Belgrade: Friedrich Eberth Stiftung, Centar za demokratiju Fakulteta političkih nauka.

\section{About the Authors}

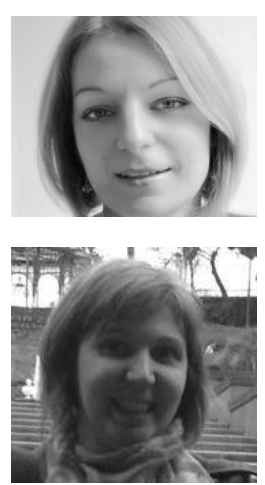

\section{Jelena Vidojević}

Jelena Vidojević is Teaching Assistant at the Department of Social Policy and Social Work at the Faculty of Political Sciences, University of Belgrade. Her research interests are international development, the welfare state and national social policies.

\section{Dr. Natalija Perišić}

Natalija Perišić is Assistant Professor at the Department of Social Policy and Social Work at the Faculty of Political Sciences, University of Belgrade. Her primary research interests are the welfare state, national and European social policies. Her main publication is Social policy-Challenges and perspectives of Europeanization (in Serbian) published by Zadužbina Andrejević of Belgrade in 2008. 